\title{
Long-acting insulin analogues elicit atypical signalling events mediated by the insulin receptor and insulin-like growth factor-I receptor
}

\author{
E. Yehezkel • D. Weinstein • M. Simon • R. Sarfstein • \\ Z. Laron $\cdot$ H. Werner
}

Received: 23 May 2010 / Accepted: 5 August 2010 / Published online: 12 September 2010

(C) Springer-Verlag 2010

\begin{abstract}
Aims/hypothesis Insulin analogues were developed to improve the pharmacological properties of injected insulin and to better mimic endogenous insulin output. However, certain insulin analogues have been suggested to display IGF-I-like biological activities. Furthermore, several recent epidemiological studies have suggested a potential increase in cancer risk for treatment of diabetes patients with longacting analogue insulin glargine (A21Gly,B31Arg,B32Arg human insulin). Additional studies, however, reported no increased cancer risk. The purpose of the present study was to identify the receptor(s) and signal transduction pathways responsible for the biological actions of insulin glargine and insulin detemir (B29Lys[ $\varepsilon$-tetradecanoyl],desB30 human insulin).

Methods The colon cancer-derived cell line HCT116 was treated with increasing doses of insulin glargine, insulin detemir, regular insulin or IGF-I, and receptor activation was evaluated by immunoprecipitation assays. IGF-I receptor (IGF-IR) internalisation following insulin glargine treatment was assessed by confocal microscopy. Activation of the Akt and extracellular signal-regulated kinase pathways was evaluated by western blots. The anti-apoptotic
\end{abstract}

E. Yehezkel, D. Weinstein and M. Simon contributed equally to this paper.

E. Yehezkel • D. Weinstein · M. Simon · R. Sarfstein •

H. Werner $(\bowtie)$

Department of Human Molecular Genetics and Biochemistry,

Sackler School of Medicine, Tel Aviv University,

Tel Aviv 69978, Israel

e-mail: hwerner@post.tau.ac.il

Z. Laron

Endocrine and Diabetes Research Unit, Schneider Children's

Medical Center,

Petah Tikva, Israel effect of the analogues was measured by poly-(ADP ribose) polymerase antibody and annexin assays.

Results We found evidence for dual activation of the insulin receptor and IGF-IR by the analogues. Dosedependency experiments showed that insulin glargine was able to phosphorylate the IGF-IR at fivefold lower doses than those required to activate the insulin receptor. We also showed that insulin glargine can lead to prolonged activation of the receptors and therefore promote abnormal signalling. Confocal imaging experiments showed that insulin glargine, but not regular insulin induced IGF-IR internalisation similarly to IGF-I. Finally, both analogues displayed IGF-I-like anti-apoptotic activities and stimulated cell cycle progression.

Conclusions/interpretation Our data indicate that insulin glargine and insulin detemir display atypical signalling activities that differ from those elicited by regular insulin and involve activation of the anti-apoptotic IGF-IR.

Keywords Analogues · Detemir · Glargine · IGF-I · IGF-I receptor · Insulin · Insulin-like growth factor-I · Signalling
Abbreviations
ERK Extracellular signal-regulated kinase
GFP Green fluorescent protein
IGF-IR Insulin-like growth factor-I receptor
PARP Poly-(ADP ribose) polymerase

\section{Introduction}

Exogenous insulin is the only therapy available for type 1 diabetes, but is also used to treat type 2 diabetes [1]. Ideally, insulin therapy should mimic normal endogenous 
insulin secretion, which occurs in two distinct patterns of discharge: bolus (postprandial) and basal (constitutive) secretions. In recent years, insulin analogues were developed to improve the pharmacological properties of injected insulin and to better mimic endogenous insulin output [2-4]. Produced by DNA recombinant technologies, insulin analogues can be divided into two major subgroups: shortacting and long-acting, according to absorption rates and action kinetics. Short-acting analogues are absorbed rapidly in capillaries, resulting in quick onset of action that resembles physiological postprandial secretion. Long-acting analogues, on the other hand, have slow and constant absorption rates that mimic basal insulin secretion.

The majority of modifications in insulin analogues were introduced into the $\mathrm{C}$-terminus of the $\mathrm{B}$-chain because this domain was not considered critical for binding of the ligand to the insulin receptor [2]. For example, insulin glargine (A21Gly,B31Arg,B32Arg human insulin), a long-acting analogue, differs from native insulin by the addition of two arginine residues at the C-terminal end of the B-chain and replacement of asparagine by glycine at position A21. The net consequence of these modifications is reduced solubility at neutral $\mathrm{pH}$, leading to the formation of a microprecipitate at the injection site, which gradually dissociates and is absorbed into capillaries [5]. Longacting insulin analogue insulin detemir (B29Lys[ $[$ tetradecanoyl],desB30 human insulin), on the other hand, was generated by omitting a threonine residue at position B30 and by acylation of a lysine residue at position B29 with myristic acid, a C14 fatty acid chain. Insulin detemir binds in the blood to albumin via its fatty acid moiety [6]. The major protraction occurs via albumin binding and stabilisation of the hexamer by myristic acid in the subcutis at the injection depot, a process that results in delayed absorption.

The IGFs, IGF-I and IGF-II, are structurally and functionally related to insulin [7]. Similarly, the IGF-I receptor (IGF-IR), which mediates most of the biological actions of IGF-I and IGF-II, displays a large similarity to the insulin receptor. Whereas the insulin receptor is mainly involved in mediating metabolic types of action, the IGF-IR primarily mediates growth and differentiation activities [8]. Furthermore, the IGF-IR has been correlated with various neoplastic processes and is over-abundant in many types of cancer [9]. Consistent with the remarkable homology between the various insulin-like ligands and their receptors, there is a certain degree of cross-talk within this growth factor family. In general, however, insulin and IGF-I display reduced affinity toward the opposite receptor [10].

Given that some of the modifications introduced into insulin analogues are located in a domain involved in a potential interaction with the IGF-IR, it has been postulated that certain analogues may display IGF-I-like activities
[11-13]. In a recent study, we investigated the biological actions of a series of long-acting and short-acting insulin analogues in cell lines derived from human cancers [14]. The actions evaluated included enhancement of cancer cell proliferation and protection from apoptosis. Our results indicated that, unlike regular human insulin, insulin glargine and insulin detemir exhibit IGF-I-like proliferative activities in colon, breast and prostate cancer cell lines in vitro. In view of the cross-talk between the insulin-like molecules and their receptors, the present study was designed to identify the receptor(s) and signal transduction pathways responsible for the biological actions of the longacting insulin analogues, glargine and detemir. Our results indicate that both of these analogues display atypical signalling activities, which differ from those elicited by regular human insulin and involve activation of the antiapoptotic IGF-IR.

\section{Methods}

Cell line and hormone treatments The human colorectal cancer cell line HCT116 was grown in RPMI-1640 medium supplemented with $10 \% \mathrm{FBS}$ (vol./vol.), $2 \mathrm{mmol} / \mathrm{l}$ glutamine, $50 \mu \mathrm{g} / \mathrm{ml}$ gentamicin sulfate and $2.5 \mu \mathrm{g} / \mathrm{ml}$ fungizone. Starvation (serum-free) medium contained 1\% BSA (wt/vol.). HCT116 cells were kindly provided by B. Vogelstein (Johns Hopkins University School of Medicine, Baltimore, MD, USA). Cells were treated with the following hormones and analogues: regular insulin (Humalin R; Lilly, Fegersheim, France); insulin glargine (Lantus; sanofi-aventis, Frankfurt, Germany); insulin detemir (Levemir; NovoNordisk, Bagsværd, Denmark); and IGF-I (CytoLab, Rehovot, Israel). The stock concentration of regular insulin and insulin analogue was $100 \mathrm{IU} / \mathrm{ml}$, the stock concentration of IGF-I was $1 \mathrm{mg} / \mathrm{ml}$. For conversion to SI units, a dose of $10 \mathrm{ng} / \mathrm{ml}$ of insulin or glargine is equivalent to $1.6 \mathrm{nmol} / 1$ and a similar dose of IGF-I is equivalent to $1.3 \mathrm{nmol} / \mathrm{l}$.

Western blots Cells were serum-starved overnight and then treated with insulin glargine, insulin detemir, IGF-I or human insulin at the indicated concentrations for $10 \mathrm{~min}$. Cells were collected with ice-cold PBS containing $5 \mathrm{mmol} / \mathrm{l}$ EDTA and lysed in lysis buffer $(150 \mathrm{mmol} / \mathrm{l} \mathrm{NaCl}$, $20 \mathrm{mmol} / 1$ HEPES, pH 7.5, 1\% Triton X-100 (vol./vol.), $2 \mathrm{mmol} / \mathrm{l} \mathrm{EDTA}, 2 \mathrm{mmol} / \mathrm{l} \mathrm{EGTA}, 1 \mathrm{mmol} / 1$ phenylmethylsulfonyl fluoride, $2 \mu \mathrm{g} / \mathrm{ml}$ aprotinin, $1 \mathrm{mmol} / 1$ leupeptin, $1 \mathrm{mmol} / \mathrm{l}$ pyrophosphate, $1 \mathrm{mmol} / 1$ vanadate and $1 \mathrm{mmol} / 1$ dithiothreitol). Samples (50 $\mu \mathrm{g}$ protein) were subjected to $10 \%$ SDS-PAGE (wt/vol.), followed by transferral of proteins to nitrocellulose membranes. Membranes were blocked with $3 \%$ fat ('fat-free') milk (vol./vol.) in TweenTris buffered saline [20 mmol/l Tris-HCl, $\mathrm{pH} 7.5,135 \mathrm{mmol} / 1$ 
$\mathrm{NaCl}$ and $0.1 \%$ Tween-20 (vol./vol.)] and incubated with antibodies against: (1) total IGF-IR $\beta$-subunit; (2) total extracellular signal-regulated kinase (ERK); (3) phosphoERK (Thr ${ }^{202} / \mathrm{Tyr}^{204}$ ); (4) total and phospho-AKT (Santa Cruz Biotechnology, Santa Cruz, CA, USA); and (5) total insulin receptor $\beta$-subunit (Cell Signaling Technology, Danvers, MA, USA). Proteins were detected using SuperSignal West Pico Chemiluminescent Substrate (Pierce, Rockford, IL, USA).

Immunoprecipitation assays Cell lysates (70 $\mu \mathrm{g})$ were immunoprecipitated by incubating overnight at $4^{\circ} \mathrm{C}$ with anti-IGF-IR $\beta$-subunit $(1: 40)$ or anti-insulin receptor $\beta$ subunit (1:50). Protein A-G agarose beads $(30 \mu \mathrm{l})$ were added to the samples and incubated for $2 \mathrm{~h}$. Then samples were washed with PBS, mixed with sample buffer, boiled for $5 \mathrm{~min}$ at $95^{\circ} \mathrm{C}$ and electrophoresed through $10 \%$ SDSPAGE. Finally, membranes were blotted as described above with anti-phosphotyrosine, anti-IGF-IR $\beta$-subunit or antiinsulin receptor $\beta$-subunit.

Confocal microscopy analysis HCT116 cells were plated on cover slips in six-well plates $\left(5 \times 10^{3}\right.$ cells/well) for $24 \mathrm{~h}$. Cells were transfected with a plasmid encoding the full-length $I G F 1 R$ cDNA fused to a green fluorescent protein (GFP) marker. The plasmid was kindly provided by R. O'Connor (Department of Biochemistry, University of Cork, Cork, Ireland). After $48 \mathrm{~h}$, cells were treated with insulin glargine, regular insulin or IGF-I for 20, 40 or $60 \mathrm{~min}$, and washed with PBS. Fixation was performed with $100 \%$ methanol for $20 \mathrm{~min}$ at $-20^{\circ} \mathrm{C}$, after which cells were washed with PBS and stained with DAPI $(5 \mu \mathrm{g} / \mathrm{ml})$ for $5 \mathrm{~min}$. Cover slips were mounted on microscope slides and visualised using a confocal microscope (SP5; Leica, Wetzlar, Germany).

Apoptosis analyses HCT116 cells were plated on 6-well plates $\left(5 \times 10^{5}\right.$ cells/well). After $24 \mathrm{~h}$, the medium was changed to starvation medium (containing 1\% [wt/vol.] BSA) and grown for an additional $24 \mathrm{~h}$, after which cells were treated with the various ligands at a dose of $50 \mathrm{ng} / \mathrm{ml}$. Following hormonal stimulation, cells were collected, washed and centrifuged. Apoptosis was evaluated by western blots using a poly-(ADP ribose) polymerase (PARP) antibody. In addition, apoptosis was measured using a kit (Annexin V-FITC Apoptosis Detection Kit; Bender Med Systems, Vienna, Austria). Briefly, annexin V-FITC was added to the cell suspension and incubated for $10 \mathrm{~min}$ in the dark. Propidium iodide was added and stained cells analysed using a flow cytometer (FACSort; Beckton Dickinson, Franklin Lakes, NJ, USA).

Cell cycle analysis Cells were plated and treated with the various ligands as described in the previous section. Cell pellets were washed with PBS and centrifuged, after which $500 \mu \mathrm{l}$ PBS and $25 \mu \mathrm{l}$ Triton X-100 4\% were added. Cells were dyed with propidium iodide at a final concentration of $50 \mu \mathrm{g} / \mathrm{ml}$. DNA content was analysed by FACSort and the Windows Multiple Document Interface for Flow Cytometry software package (WinMDI 2.9; Scripps Research Institute, La Jolla, CA, USA).

Statistical analysis The statistical significance of differences between experimental groups was assessed by Student's $t$ test (two samples, equal variance) with a $p$ value of $99 \%$.

\section{Results}

To investigate the signalling pathways involved in insulin analogues action in colon cancer cells, our initial experiments measured the basal levels of insulin receptor and IGF-IR in the HCT116 cell line. As shown in Fig. 1a, b, HCT116 cells express both receptors at similar levels. These results were confirmed by immunofluorescent microscopy using anti-IGF-IR and anti-insulin receptor antibodies (data not shown). Incubation of the cells for $24 \mathrm{~h}$ in serum-free (starvation) medium had no effect on basal receptor levels (Fig. 1a, b). To identify the specific receptor(s) activated by insulin glargine in comparison to regular human insulin or IGF-I, confluent cells were maintained overnight in starvation medium, after which they were treated with a physiological dose of insulin glargine $(50 \mathrm{ng} / \mathrm{ml})$ for $10 \mathrm{~min}$. At the end of the incubation, receptor phosphorylation was evaluated by immunoprecipitation assays. Specifically, lysates were immunoprecipitated with anti-insulin receptor (Fig. 1c) or anti-IGF-IR (Fig. 1d) for $24 \mathrm{~h}$, electrophoresed through 10\% SDS-PAGE and immunoblotted with antiphosphotyrosine. Results showed that, at a dose of $50 \mathrm{ng} / \mathrm{ml}$, each receptor was preferentially activated by its cognate ligand, with minimal cross-activation by the heterologous hormone. Similarly to regular insulin, insulin glargine also stimulated insulin receptor phosphorylation; in addition, it also phosphorylated the IGF-IR in an IGF-I-like manner.

Next, we characterised the dose-dependency of insulin receptor and IGF-IR activation by insulin glargine. To this end, starved cells were treated with increasing doses of insulin glargine, regular insulin or IGF-I $(5,10,25,50$ or $100 \mathrm{ng} / \mathrm{ml}$ ) for $10 \mathrm{~min}$, while untreated cells served as controls. Cells were then collected and receptor activation assessed by immunoprecipitation assays, as described above. The results revealed that insulin glargine induced insulin receptor phosphorylation in a dose-dependent manner at doses of 5 to $25 \mathrm{ng} / \mathrm{ml}$ (Fig. 2a, c). Regular insulin, on the other hand, induced almost maximal insulin 

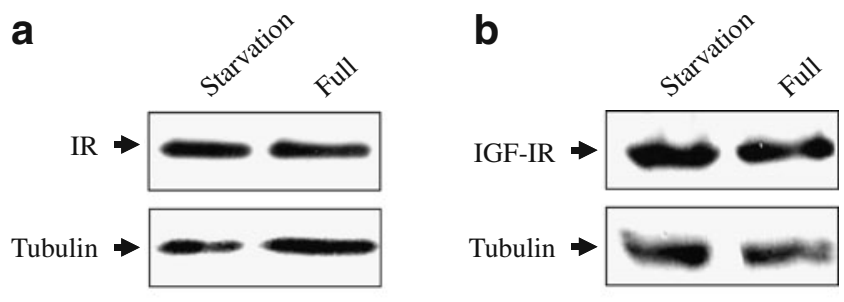

C

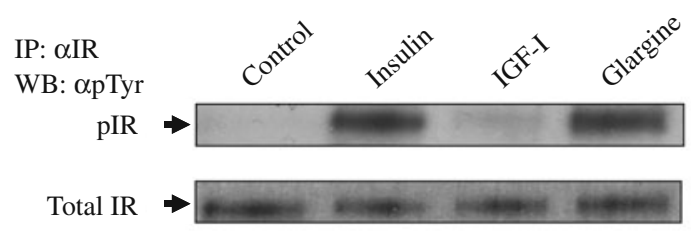

d

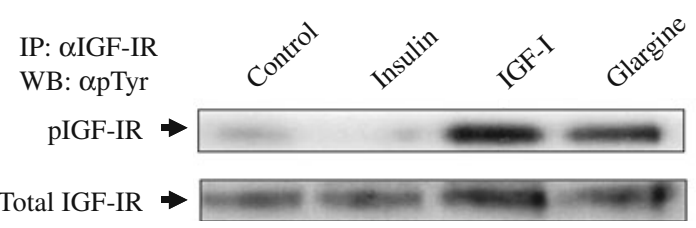

Fig. 1 Activation of the insulin receptor and IGF-IR by insulin glargine and insulin detemir. HCT116 cells were grown to $100 \%$ confluence, after which the medium was changed to $10 \%$ FBScontaining ('full-medium') or serum-free media ('starvation medium'). After $24 \mathrm{~h}$, cells were collected and basal insulin receptor (IR) (a) and IGF-IR (b) levels were measured by western blots using antibodies against the $\beta$-subunit of the corresponding receptor. Tubulin levels were measured as a loading control. c To compare the activating potential of insulin glargine with that of regular insulin or IGF-I, starved cells were treated with the ligands $(50 \mathrm{ng} / \mathrm{ml})$ for $10 \mathrm{~min}$, after which cells were collected, immunoprecipitated (IP) with anti-insulin receptor $(\alpha \mathrm{IR})$ or $(\mathbf{d})$ anti-IGF-IR ( $\alpha$ IGF-IR) for $24 \mathrm{~h}$, electrophoresed through $10 \%$ SDS-PAGE and immunoblotted with antiphosphotyrosine ( $\alpha \mathrm{p}$ Tyr). Membranes were then incubated with antibodies against total insulin receptor or IGF-IR to confirm equal loading of samples. Experiments were repeated at least three times with similar results. Typical autoradiograms are presented. WB, western blotting

receptor phosphorylation at the lowest concentration studied $(5 \mathrm{ng} / \mathrm{ml})$. In addition, insulin glargine, similarly to IGF-I, activated the IGF-IR at a dose of $5 \mathrm{ng} / \mathrm{ml}$, whereas regular insulin was unable to stimulate IGF-IR phosphorylation at the doses studied (Fig. 2b, d). Equal loading was assessed by blotting the membranes with antibodies against total insulin receptor or IGF-IR. Together, the results of dose-dependent activation assays indicate that maximal insulin receptor phosphorylation was seen at a dose of $25 \mathrm{ng} / \mathrm{ml}$ insulin glargine, whereas maximal IGF-IR phosphorylation was detected at fivefold lower doses of the analogue.

Given that insulin glargine is a long-acting analogue, we evaluated receptor activation over longer periods of time. For this purpose, cells were treated with insulin glargine $(50 \mathrm{ng} / \mathrm{ml})$ and receptor activation was assessed by immunoprecipitation after various periods of time $(5,20$ and $40 \mathrm{~min}$, and 1, 2, 4 and $6 \mathrm{~h}$ ). Results indicate that insulin glargine induced sustained insulin receptor phosphorylation (up to 6 h; Fig. 3a, c), whereas its pattern of IGF-IR activation was bi-phasic, with activation peaks at 5 min and 2 h (Fig. 3b, d). In comparison, regular insulin phosphorylated the insulin receptor in a very rapid and transient fashion (Fig. 3e).

Next, we evaluated the ability of insulin detemir to activate the IGF-IR. To this end starved cells were incubated with increasing doses of the analogue $(5,25,50$ and $100 \mathrm{ng} / \mathrm{ml}$ ) for $20 \mathrm{~min}$ (Fig. 4a). In addition, cells were treated with insulin detemir for longer periods of time (1, $2 \mathrm{~h}$ ) at a dose of $50 \mathrm{ng} / \mathrm{ml}$ (Fig. 4b). At the end of the incubation period, cell lysates were prepared and IGF-IR phosphorylation was assessed by immunoprecipitation assays, as described above. The results revealed that insulin detemir induced IGF-IR phosphorylation in a dosedependent manner. However, at the short incubation period (20 $\mathrm{min}$ ) insulin detemir was approximately one order of magnitude less potent than IGF-I. After a longer incubation time $(1 \mathrm{~h})$, the effect of insulin detemir was comparable to that of IGF-I, although this effect was not sustained, with a marked reduction of insulin detemir-induced IGF-IR activation noted after $2 \mathrm{~h}$.

To evaluate the ability of insulin glargine to stimulate IGF-IR internalisation and redistribution, cells were transfected with an IGF-IR-encoding expression vector fused to a GFP tag. After $48 \mathrm{~h}$, cells were treated with insulin, IGF-I or insulin glargine for 20,40 or $60 \mathrm{~min}$, and fixed for confocal microscopy. Figure 5 shows the results of IGF-IR internalisation analysis at $40 \mathrm{~min}$. Control cells expressed the IGF-IR primarily on the cell membrane (Fig. 5a). Insulin treatment did not significantly affect the distribution of IGF-IR (Fig. 5b). When treated with IGF-I, a portion of the tagged receptor displayed, in addition to its cell-surface distribution, a perinuclear localisation, implying IGF-IR internalisation (Fig. 5c). Treatment with insulin glargine produced a similar effect to that seen with IGF-I, i.e. reduced membrane localisation and perinuclear accumulation of the IGF-IR (Fig. 5d).

To address the activation of downstream signalling molecules by insulin glargine and insulin detemir in comparison to regular insulin or IGF-I, cells were incubated with the ligands for up to $1 \mathrm{~h}$ and Akt phosphorylation was measured by western blot analysis with anti-phospho-Akt antibodies at 15, 30 and $60 \mathrm{~min}$. The results showed that insulin glargine strongly stimulated Akt phosphorylation at $30 \mathrm{~min}$, an induction that paralleled the effect of insulin (Fig. 6a, b). At this time point, IGF-I- and insulin detemirstimulated Akt phosphorylation were significantly lower. No significant differences between the ligands in terms of Akt phosphorylation were seen at $60 \mathrm{~min}$, whereas at 15 min basal Akt phosphorylation was elevated and no 
a

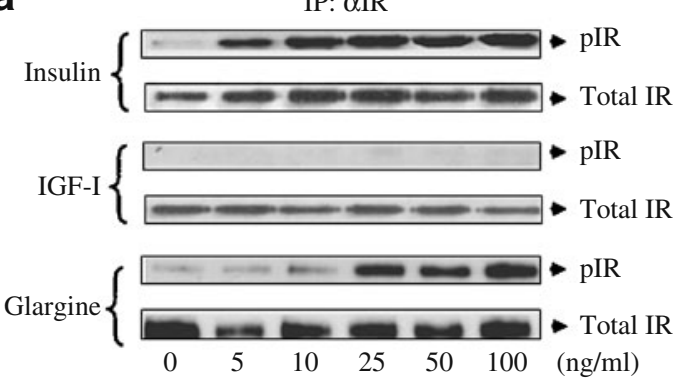

C

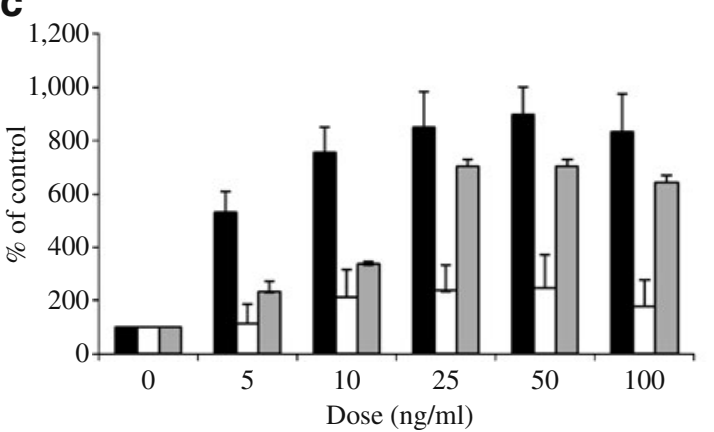

Fig. 2 Dose-dependent activation of insulin receptor and IGF-IR by insulin glargine. Confluent HCT116 cells were transferred to starvation medium for $24 \mathrm{~h}$, after which they were incubated with the indicated doses of insulin glargine, regular insulin or IGF-I for $10 \mathrm{~min}$. Cell lysates were immunoprecipitated with anti-insulin receptor (IR) (a) or anti-IGF-IR (b), and electrophoresed and blotted with antiphosphotyrosine. Membranes were then incubated with total anti-IR b

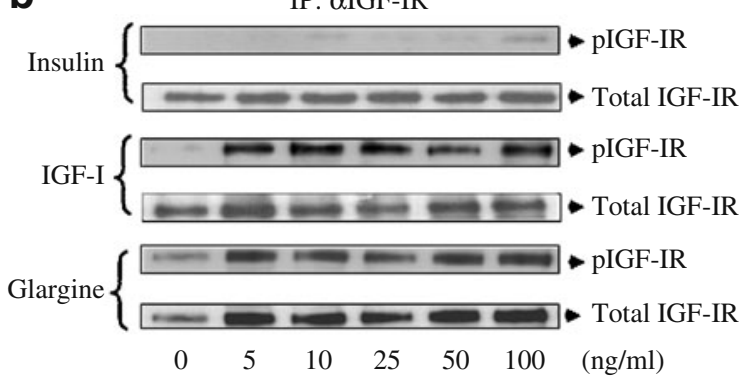

d

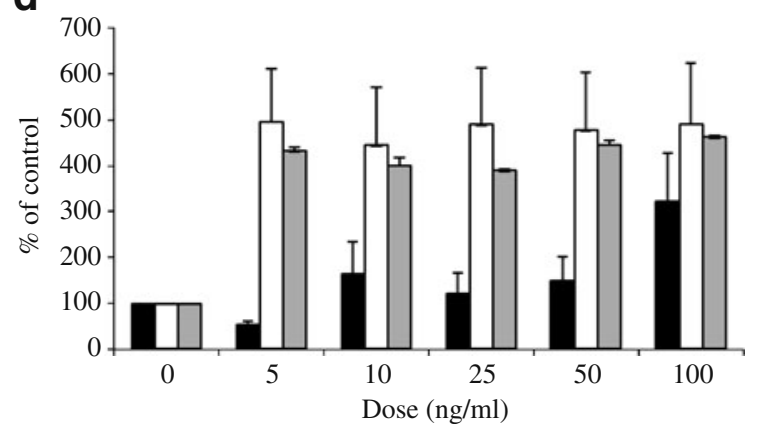

(a) or total anti-IGF-IR (b) as a loading control. Autoradiographs are of typical experiments repeated at least three times with similar results. c Scanning densitometry analyses of the effects of insulin (black bars), IGF-I (white bars) and insulin glargine (grey bars) on insulin receptor and (d) IGF-IR phosphorylation. Bars are mean \pm SEM of three independent experiments. A value of $100 \%$ was assigned to the phosphorylation levels in untreated cells a

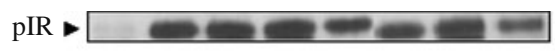

Total IR
Time (min)

C

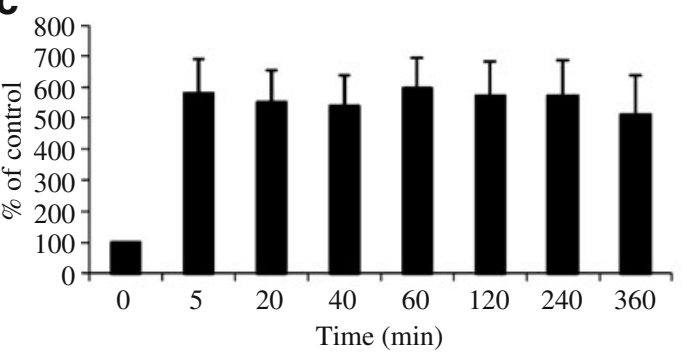

b
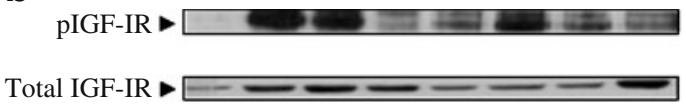

Time (min) $\begin{array}{lllllllll} & 0 & 5 & 20 & 40 & 60 & 120 & 240 & 360\end{array}$

d

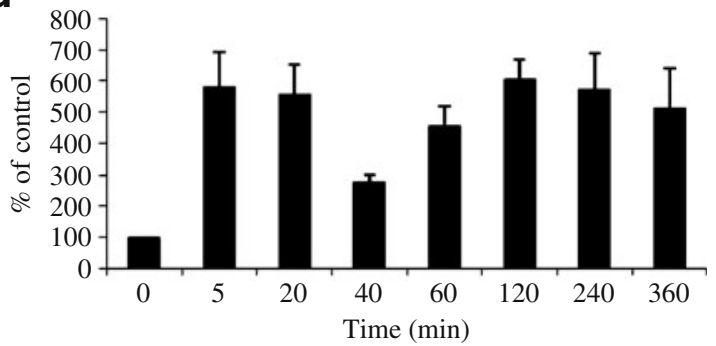

e

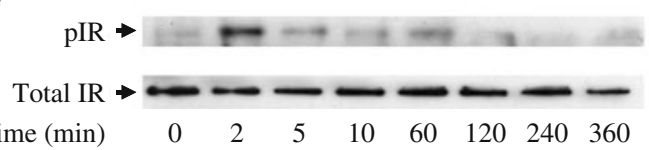

Fig. 3 Time-dependent activation of insulin receptor and IGF-IR by insulin glargine. a, b Starved HCT116 cells were incubated with insulin glargine $(50 \mathrm{ng} / \mathrm{ml})$ for increasing periods of time. Insulin receptor (IR) (a) and IGF-IR (b) phosphorylation were measured by immunoprecipitation assays as described in the legend to Fig. 1.
Scanning densitometry analyses of the effect of insulin glargine on insulin receptor (c) and (d) IGF-IR phosphorylation. Bars are mean \pm SEM of three independent experiments. e Immunoprecipitation analysis of insulin receptor phosphorylation by regular insulin 

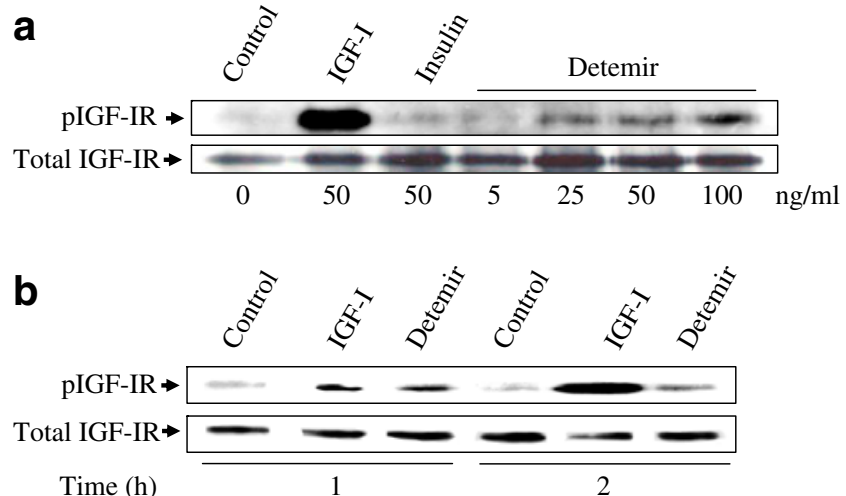

Fig. 4 Dose- and time-dependent activation of IGF-IR by insulin detemir. Confluent HCT116 cells were transferred to starvation medium for $24 \mathrm{~h}$, after which they were incubated with the indicated doses of insulin detemir, regular insulin or IGF-I for $20 \mathrm{~min}(\mathbf{a})$, or 1 or $2 \mathrm{~h} \mathrm{(b).} \mathrm{The} \mathrm{ligand} \mathrm{dose} \mathrm{used} \mathrm{for} \mathrm{the} 1$ and $2 \mathrm{~h}$ incubations was $50 \mathrm{ng} / \mathrm{ml}$. Cell lysates were immunoprecipitated with anti-IGF-IR, electrophoresed and blotted with anti-phosphotyrosine. To confirm equal loading of samples, membranes were re-probed with anti-total IGF-IR

stimulation was seen (not shown). On the other hand, glargine- and detemir-induced ERK1/2 phosphorylation, as measured by western blots with anti-phospho-ERK1/2 antibodies, paralleled the effect of IGF-I (Fig. 6c, d). Under our experimental conditions, regular insulin exhibited the strongest potency at all time points. Notably, the ability of insulin glargine and insulin detemir to activate ERK1/2 was largely reduced at $60 \mathrm{~min}$.

Next, the potential protection from apoptosis afforded by insulin glargine and insulin detemir were evaluated. To this end, cells were starved for $24 \mathrm{~h}$, after which they were treated with the various ligands at a dose of $50 \mathrm{ng} / \mathrm{ml}$ for an additional $24 \mathrm{~h}$. Cells were collected and apoptosis was assessed by western blot using anti-PARP. The results show that insulin glargine and insulin detemir treatments were associated with $21 \%$ and $50 \%$ reductions respectively (vs control cells) in the intensity of the $\sim 85 \mathrm{kDa}$ band, which represents a cleavage product of the full-length PARP $(\sim 116 \mathrm{kDa})$ and serves as a marker of cells undergoing apoptosis (Fig. 7a-c). The intensity of the $\sim 85 \mathrm{kDa}$ band in insulin-treated cells was similar to that in control cells, consistent with a reduced anti-apoptotic effect. As expected, use of IGF-I led to a $58 \%$ reduction in PARP cleavage. These results were corroborated using an Annexin V-FITC kit. FACS analysis revealed that IGF-I and insulin glargine reduced the proportion of apoptotic cells from $5.1 \pm 0.4 \%$ to $3.1 \pm 0.7 \%$ and $2.8 \pm 0.6 \%$, respectively, whereas insulin had no protective effect (Fig. 7d). Finally, we evaluated the ability of insulin glargine to stimulate cell cycle progression. For this purpose cells were treated with $50 \mathrm{ng} / \mathrm{ml}$ of insulin glargine, insulin or IGF-I for $10 \mathrm{~h}$, and collected for cell cycle analysis. Untreated cells were used as control. Cells were dyed with propidium iodide and analysed by FACS for DNA content. Quantification of the cell fraction at S-phase revealed that insulin glargine, similarly to IGF-I, enhanced the fraction of cells at S-phase (Fig. 7e). Insulin, on the other hand, had no effect on cell cycle progression.

\section{Discussion}

Results of epidemiological studies linking diabetes mellitus with cancer prevalence are controversial; however, diabetes seems to be a risk factor for various tumours, including colon, pancreas, breast and liver cancers [15]. In the specific context of colorectal cancer, recent epidemiological studies have provided evidence that hyperinsulinaemia and hyperglycaemia confer an increased cancer risk in patients with type 2 diabetes [16, 17]. Thus, in a retrospective cohort study among all patients with a diagnosis of type 2 diabetes mellitus in the General Practice Research Database from the UK, chronic insulin therapy was shown to significantly increase the risk of colorectal cancer among type 2 diabetes patients (197 cancer cases per 100,000 person-years in insulin users, compared with 124 cancer cases per 100,000 person-years in patients not receiving insulin) [16].

The use of insulin analogues as a replacement therapy to physiological insulin allows more convenient and flexible diabetes management. However, the spectrum of biological activities elicited by insulin analogues has been controversial, and serious safety concerns regarding the mitogenic
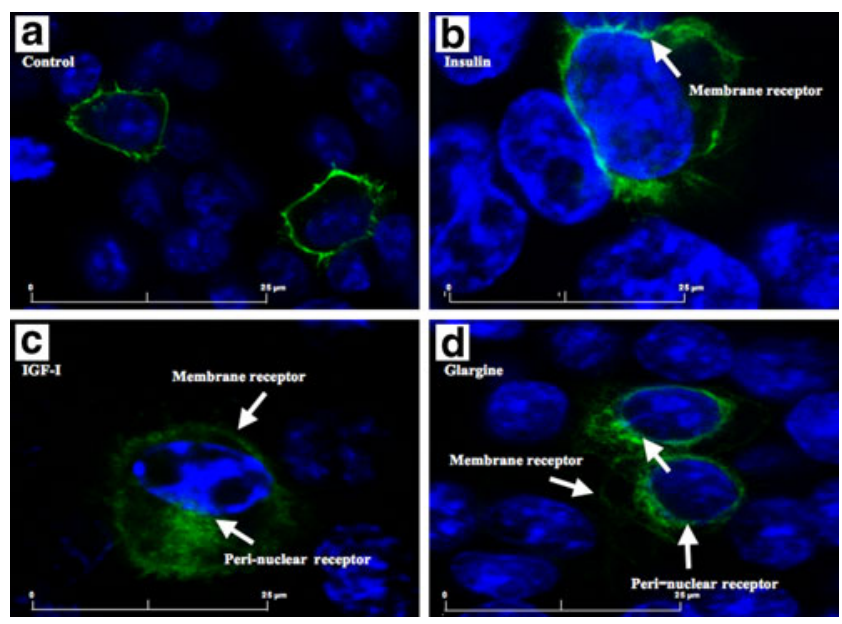

Fig. 5 Insulin glargine-induced IGF-IR internalisation. HCT116 cells were plated on cover slips in 6-well plates for $24 \mathrm{~h}$. Cells were then transfected with a plasmid containing IGFIR cDNA fused to a GFP marker $(1 \mu \mathrm{g})$. After $48 \mathrm{~h}$, the cells were (a) left untreated (control) or treated with $50 \mathrm{ng} / \mathrm{ml}$ regular insulin (b), IGF-I (c) or insulin glargine (d) for 20, 40 or $60 \mathrm{~min}$ respectively, and fixed for confocal microscopy. Results shown were obtained after $40 \mathrm{~min}$ in experiments repeated three times 
a

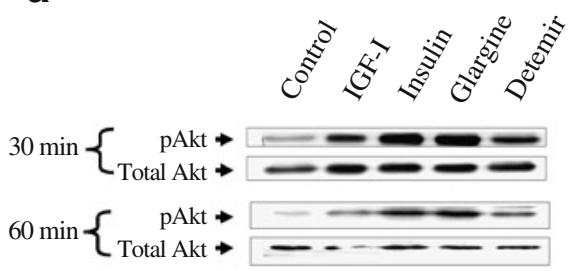

b

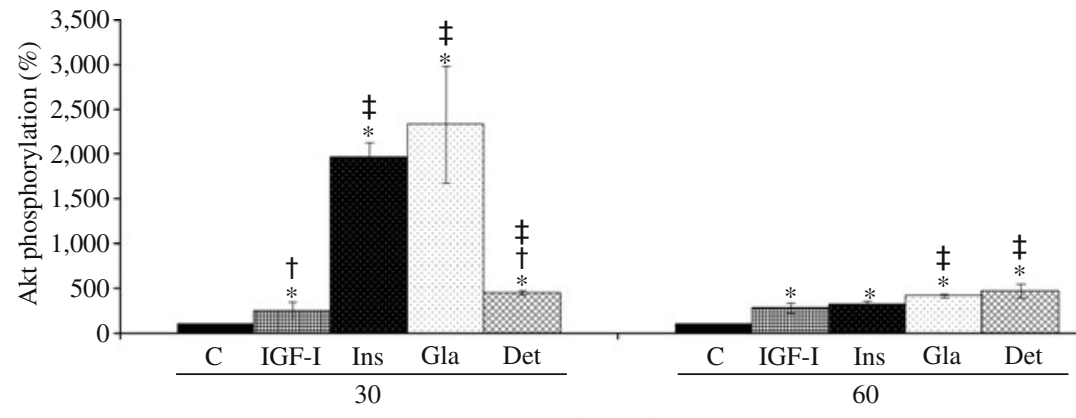

Time (min)

d

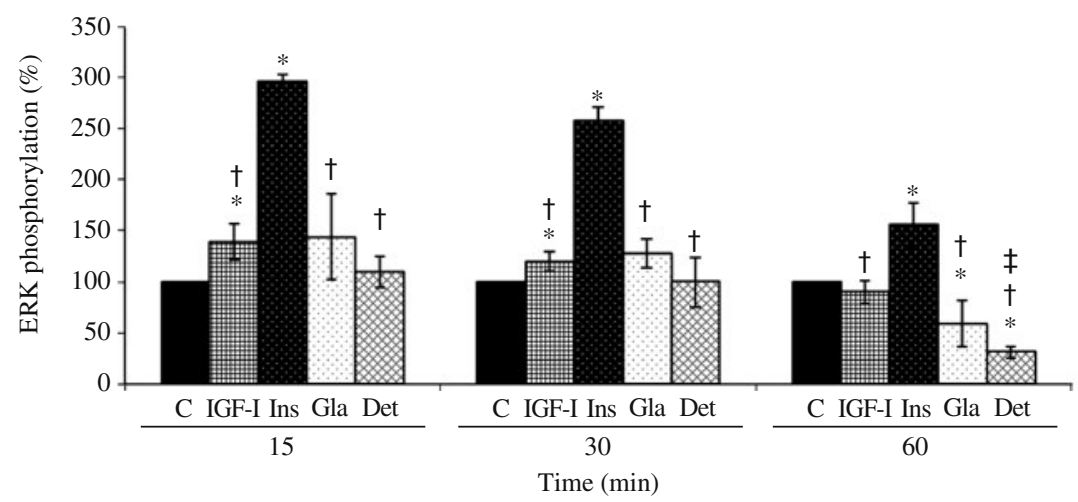

Fig. 6 Activation of Akt and ERK by insulin glargine and insulin detemir. HCT116 cells were plated in six-well plates. After reaching confluence, cells were transferred to starvation medium for $24 \mathrm{~h}$ and then treated with insulin, IGF-I, insulin glargine or insulin detemir at a dose of $50 \mathrm{ng} / \mathrm{ml}$ for $60 \mathrm{~min}$. Cells were collected after 15, 30 and $60 \mathrm{~min}$, and analysed by western blot for $(\mathbf{a}, \mathbf{b})$ phospho- and total Akt, and (c, d) phospho- and total-ERK1/2. Activated Akt and ERK1/2 were measured using specific anti-phospho-Akt and anti-ERK1/2 antibodies. Bars represent mean \pm SEM of three independent experiments. ${ }^{*} p<0.05$ vs control cells; ${ }^{\dagger} p<0.05$ vs insulin-treated cells; ${ }^{\ddagger} p<0.05$ vs IGF-Itreated cells. C, control; Ins, insulin; Gla, insulin glargine; Det, insulin detemir

insulin analogues treatment and cancer risk was seen in a UK-based study [22]. However, the methodology and interpretation of epidemiological data was criticised by other authors. For example, Nagel et al. [23] indicated that the study by Hemkens et al. [19] compared subsets of patients that cannot easily be compared. Nagel observed that patients with either type 1 or type 2 diabetes mellitus were included, although the type and frequency of malignancies associated with either disease are different. In addition, Nagel criticised the fact that Hemkens et al. explained the overall lower cancer incidence in the insulin glargine group as 'an imbalance in the distribution of dose groups'.

The present study provides empirical evidence for dual activation of the insulin receptor and IGF-IR by insulin glargine and insulin detemir. Specifically, dose-dependency experiments showed that insulin glargine was able to phosphorylate the IGF-IR at fivefold lower doses than those required to activate the insulin receptor (i.e. $5 \mathrm{ng} / \mathrm{ml}$ insulin glargine were required for maximal IGF-IR phosphorylation compared with $25 \mathrm{ng} / \mathrm{ml}$ required to activate the insulin receptor; Fig. 2). Our data also indicate that insulin glargine can lead to prolonged activation of the including 49,197 patients $[20,21]$. No correlation between 


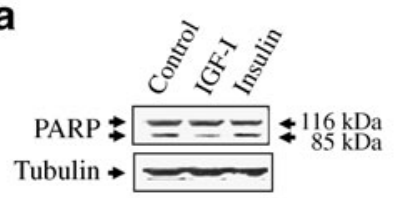

b

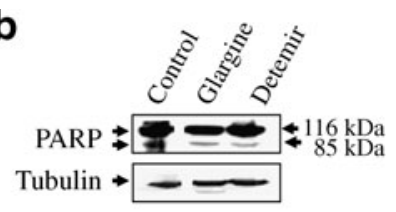

C

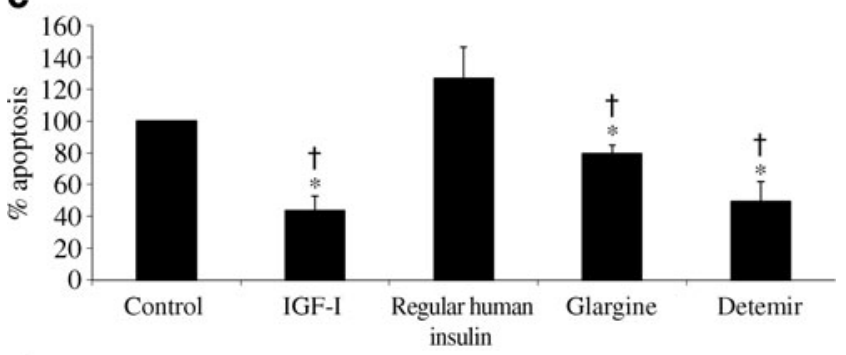

d
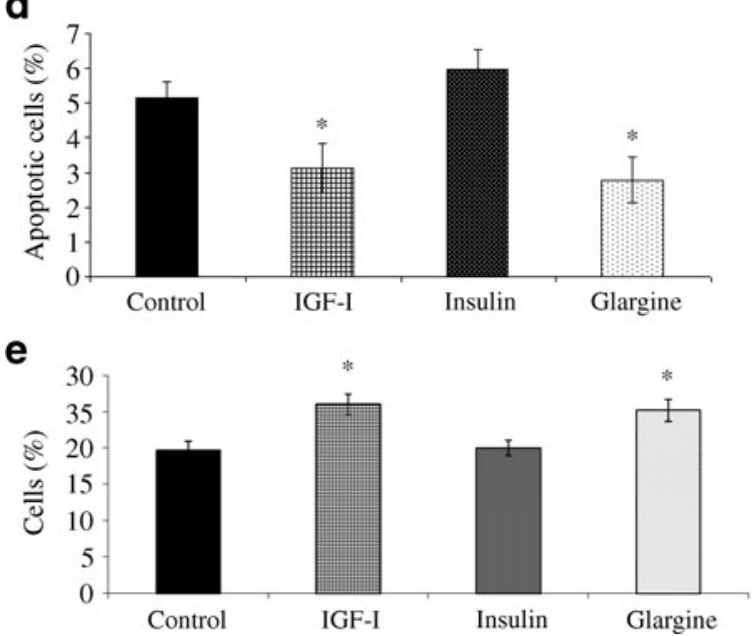

Fig. 7 Analysis of the anti-apoptotic activities of insulin glargine and insulin detemir. a Starved HCT116 cells were incubated for $24 \mathrm{~h}$ with $50 \mathrm{ng} / \mathrm{ml} \mathrm{IGF-I}$ or regular insulin, and (b) insulin glargine or insulin detemir, after which cells were lysed, electrophoresed through $10 \%$ SDS-PAGE, transferred to membranes and blotted with an anti-PARP antibody. The $85 \mathrm{kDa}$ PARP band represents an early sign of apoptosis. Blots were reprobed with anti-tubulin as a loading control. c Densitometric scanning of the $85 \mathrm{kDa}$ PARP band normalised to the corresponding tubulin band for three independent experiments. Bars are mean \pm SEM. A value of $100 \%$ was assigned to the PARP/tubulin ratio in untreated (control) cells. ${ }^{*} p<0.05$ vs control; $\dagger p<0.05$ vs insulin treatment. d Starved cells were treated with $50 \mathrm{ng} / \mathrm{ml}$ regular insulin, IGF-I or insulin glargine for $12 \mathrm{~h}$ and collected for Annexin V-FITC apoptosis assay ( $n=5$ independent experiments). Bars are per cent apoptotic cells (mean $\pm \mathrm{SEM}$ ). ${ }^{*} p<0.05$ vs control and regular insulin treatment. e Cell cycle analysis. Cells were treated with the indicated hormones for $10 \mathrm{~h}$, after which they were collected for cell cycle analysis, as described in text. Bars are per cent of cells in S-phase (mean \pm SEM, $n=3$ independent experiments). ${ }^{*} p<0.05$ vs control and regular insulin treatment

receptors and therefore promote abnormal signalling (Fig. 3a-d). In comparison, regular insulin induced rapid and transient insulin receptor phosphorylation (Fig. 3e). In addition, the present study provides evidence that insulin detemir activates the IGF-IR; however, this long-acting analogue was markedly less potent than insulin glargine in this respect (Fig. 4). Interestingly, insulin glargine exhibited normal insulin receptor association in rat-1 fibroblasts overexpressing insulin receptor $\mathrm{A}$ and insulin receptor $\mathrm{B}$, but different dissociation kinetics in cells expressing insulin receptor A. Insulin glargine, in addition, induced rapid phosphorylation of the insulin receptor [24]. Kurtzhals et al. [12] reported that insulin glargine and insulin detemir differed significantly from human insulin in their binding and biological profiles. Specifically, insulin glargine exhibited a six- to eightfold increased affinity for the IGFIR compared with insulin in Chinese hamster ovary cells overexpressing the receptor and also displayed enhanced mitogenic potency in osteosarcoma cells. Insulin detemir, on the other hand, displayed a reduced receptor affinity for the IGF-IR, as well as diminished metabolic and mitogenic potencies. Comparisons between the various studies are difficult due to the many cell types and experimental conditions in which analogues were analysed. Our confocal imaging experiments showed that insulin glargine induced IGF-IR internalisation similarly to IGF-I, whereas insulin did not exhibit such activity (Fig. 5). These analyses imply a similarity in the signalling activities elicited by IGF-I and insulin glargine. Hence, although insulin analogues were designed to display insulin-like metabolic effects, our data support the notion that insulin glargine also exhibits IGF-Ilike activities and, accordingly, functions like an IGF-I analogue.

Biological studies have shown that insulin glargine and insulin detemir have a positive effect on cell cycle progression and display anti-apoptotic activities [14, 25]. These results are consistent with our signalling analyses, showing that insulin glargine exhibited IGF-I-like activity in terms of IGF-IR phosphorylation, internalisation and cellular re-distribution. However, in terms of downstream signalling activation, the picture is more complex. Thus we observed that insulin glargine activated Akt in an insulinlike manner, whereas it activated ERK similarly to IGF-I. Specifically, treatment with insulin or insulin glargine led to significant increases in phospho-Akt levels after $30 \mathrm{~min}$, with reduction to almost basal levels after $60 \mathrm{~min}$. The effects of IGF-I and insulin detemir on Akt phosphorylation were lower than those of regular insulin and insulin glargine (Fig. 6a, b). The Akt pathway is known to mediate mainly insulin metabolic effects, which could explain the finding that insulin glargine induced Akt activation in an insulin-like fashion. The ERK pathway is known to be important in terms of mitogenicity. Consistently, our data indicated that insulin glargine- and insulin detemir-induced ERK phosphorylation paralleled IGF-I-induced activation at all time points studied (Fig. 6c, d). The biological implications of the atypical signalling patterns of insulin glargine and detemir need to be further investigated. 
In summary, the present study provides evidence for insulin glargine- and insulin detemir-induced dual activation of the insulin receptor and IGF-IR, and suggests that insulin glargine, unlike regular insulin, can activate both receptors for prolonged periods of time, hence promoting abnormal signalling. Insulin detemir, while capable of inducing IGF-IR phosphorylation, had a reduced effect in comparison to IGF-I and insulin glargine. Importantly, and especially given that our study was performed on a cancer cell line, no conclusions can be drawn about the potential impact of the analogues on cancer aetiology and progression. The clinical implications of the atypical signalling activities of insulin glargine and insulin detemir remain to be evaluated.

Acknowledgements The authors wish to express their gratitude to the Insulin Dependent Diabetes Trust (IDDT), Northampton, UK, for their generous support. E. Yehezkel and M. Simon performed this work in partial fulfilment of the requirements for MSc degrees at the Sackler Faculty of Medicine, Tel Aviv University. We thank R. O'Connor and B. Vogelstein for cell lines and reagents.

Duality of interest The authors declare that there is no duality of interest associated with this manuscript.

\section{References}

1. Bethel MA, Feinglos MN (2005) Basal insulin therapy in type 2 diabetes. J Am Board Fam Pract 26:199-204

2. Hirsch IB (2005) Insulin analogues. N Engl J Med 352:174-183

3. Crotty S, Reynolds SL (2007) The new insulins. Pediatr Emerg Care 23:903-905

4. Bolli GB (2003) Rational use of insulin analogues in the treatment of type 1 diabetes mellitus. Pediatr Endocrinol Rev 1:9-21

5. Dunn CJ, Plosker GL, Keating GM, McKeage K, Scott LJ (2003) Insulin glargine: an updated review of its use in the management of diabetes mellitus. Drugs 63:1743-1778

6. Hordern SV, Russell-Jones DL (2005) Insulin detemir, does a new century bring a better basal insulin? Int J Clin Pract 59:730-739

7. Werner H, Weinstein D, Bentov I (2008) Similarities and differences between insulin and IGF-I: structures, receptors, and signaling pathways. Arch Physiol Biochem 114:17-22

8. LeRoith D, Werner H, Beitner-Johnson D, Roberts CT Jr (1995) Molecular and cellular aspects of the insulin-like growth factor I receptor. Endocr Rev 16:143-163
9. Werner H, Maor S (2006) The insulin-like growth factor-I receptor gene: a downstream target for oncogene and tumor suppressor action. Trends Endocrinol Metab 17:236-242

10. Gauguin L, Klaproth B, Sajid W et al (2008) Structural basis for the lower affinity of the insulin-like growth factors for the insulin receptor. J Biol Chem 283:2604-2613

11. Hansen BF (2008) Insulin analogues with increased mitogenic potency - are they safe? Horm Metab Res 40:431-433

12. Kurtzhals P, Schaffer L, Sorensen A et al (2000) Correlations of receptor binding and metabolic and mitogenic potencies of insulin analogs designed for clinical use. Diabetes 49:999-1005

13. Le Roith D (2007) Insulin glargine and receptor-mediated signaling: clinical implications in treating type 2 diabetes. Diab Metab Res Rev 23:593-599

14. Weinstein D, Simon M, Yehezkel E, Laron Z, Werner H (2009) Insulin analogues display IGF-I-like mitogenic and antiapoptotic activities in cultured cancer cells. Diabetes Metab Res Rev 25:41-49

15. Giovannucci E, Michaud D (2007) The role of obesity and related metabolic disturbances in cancers of the colon, prostate, and pancreas. Gastroenterology 132:2208-2225

16. Yang YX, Hennessy S, Lewis JD (2004) Insulin therapy and colorectal cancer risk among type 2 diabetes mellitus patients. Gastroenterology 127:1044-1050

17. Berster JM, Goke B (2008) Type 2 diabetes mellitus as risk factor for colorectal cancer. Arch Physiol Biochem 114:84-98

18. Smith U, Gale EA (2009) Does diabetes therapy influence the risk of cancer? Diabetologia 52:1699-1708

19. Hemkens LG, Grouven U, Bender R et al (2009) Risk of malignancies in patients with diabetes treated with human insulin or insulin analogues: a cohort study. Diabetologia 52:1732-1744

20. Jonasson JM, Ljung R, Talback M, Haglund B, Gubdojornsdottir S, Steineck G (2009) Insulin glargine use and short-term cancer incidence - a population-based follow-up in Sweden. Diabetologia 52:1745-1754

21. Colhoun H, SDRN Epidemiology Group (2009) Use of insulin glargine and cancer incidence in Scotland: a study from the Scottish Diabetes Research Network Epidemiology Group. Diabetologia 52:1755-1765

22. Currie CJ, Poole CD, Gale EA (2009) The influence of glucoselowering therapies on cancer risk in type 2 diabetes. Diabetologia 52:1766-1777

23. Nagel JM, Mansmann U, Wegscheider K, Rohmel J (2010) Insulin resistance and increase risk for malignant neoplasms: confounding of the data on insulin glargine. Diabetologia 53:206-208

24. Berti L, Kellerer M, Bossenmaier B, Seffer E, Seipke G, Haring HU (1998) The long-acting human insulin analog HOE901: characteristics of insulin signalling in comparison to $\mathrm{Asp}(\mathrm{B} 10)$ and regular insulin. Horm Metab Res 30:123-129

25. Shukla A, Grisouard J, Ehemann V, Hermani A, Enzmann H, Mayer D (2009) Analysis of signaling pathways related to cell proliferation stimulated by insulin analogs in human mammary epithelial cell lines. Endocr-Relat Cancer 16:429-441 